\title{
La historia del Falcón oriol y del ave fénix en la literatura medieval castellana*
}

\author{
Sergio GuAdalajara SALMERón \\ sergio.guadalajara@ucm.es \\ Universidad Complutense de Madrid
}

\section{ETIMOLOGÍA Y ORÍGENES DEL NOMBRE «ORIOL»}

Elena y María, las dos hermanas protagonistas de uno de los debates conservados más importantes de la literatura medieval castellana (titulado precisamente Elena y María por el nombre de estos dos personajes), tratan de determinar cuál es el mejor de los amantes: el clérigo o el caballero. Tras discutir con pasión y enojarse recíprocamente, finalmente deciden que el asunto solo puede ser zanjado por un juez imparcial. Nadie mejor que un rey, concluyen, para llevar a cabo tal cometido: «Vayamos anbas a la corte de un rey/ que yo de mejor non sey: / este rey e emperador / nunca julga senon de amor» ${ }^{1}$. A partir de este momento, el realismo que ha caracterizado el poema va disminuyendo en favor de un ambiente impregnado de un mayor contenido alegórico y fantasioso. Así llegan hasta una tierra lejana, donde habita el rey Oriol:
Aquel es el rrey Oriol, señor de buen valor; non ha en todo el mundo corte mas alegre nin de mejor conorte; corte es de muy grand alegria e de plazer e de jogreria; omne non faz otro lauor senon cantar sienpre de amor; cantar e departir e viesos nuevos contrubar;

\footnotetext{
* A José Guadalajara García, fénix humano, parte de mí mismo.

Este trabajo ha sido realizado al amparo de un contrato de Formación del Profesorado Universitario del Ministerio (FPU) de Ciencia, Innovación y Universidades (ref. FPU2015/04541, regulado por BOE-A-2015-12849). Asimismo, se enmarca dentro de las actividades del proyecto I+D+i DHuMAR «Digital Humanities, Middle Ages \& Renaissance. 1. Poetry 2. Translation» (MINECO, FFI2013-44286-P) y gracias a las Ayudas para la Formación de Profesorado Universitario (MINECO).

${ }^{1}$ Ramón Menéndez Pidal, «Elena y María (Disputa del clérigo y el caballero). Poesía leonesa inédita del siglo XIII», Revista de Filología Española, 1 (1914), pp. 52-96, vv. 285-288.
} 
tanto ha entre ellos conorte,

que non han pavor de muerte ${ }^{2}$.

Oriol es rey sobre una corte medieval muy peculiar, pues no está compuesta por seres humanos, sino por aves. El anónimo autor del debate demuestra poseer en este punto ciertos conocimientos ornitológicos, pues enumera $-\mathrm{y}$, en algunos casos, incluso describe- casi una veintena de especies de aves diferentes: halcones, azores, estorninos, ruiseñores, jilgueros o palomas. Este hecho, que por sí mismo ya invita a un análisis más detallado (por el simbolismo que puedan encerrar estos cortesanos tan especiales), plantea una cuestión más trascendente que no ha sido analizada hasta el momento: Oriol es un rey acompañado por toda una corte de aves, por lo que no debe extrañar que él mismo pueda poseer esta misma naturaleza (real o figuradamente), y no la de ser humano. De hecho, es absolutamente frecuente en la literatura medieval (en especial, en la cuentística de influencia oriental) que diversos animales protagonicen obras narrativas breves, en las que adoptan comportamientos antropomórficos para potenciar el didactismo del texto u ocultar personas reales.

Durante la Edad Media, Oriol fue -y hoy continúa siendo- un nombre muy extendido en los territorios pertenecientes a la Corona de Aragón. Su etimología es resultado de la evolución fonética del adjetivo latino aureolus, que significa 'dorado'. El oro, por sus cualidades, escasez y alto valor, es el color que habitualmente han utilizado las monarquías para decorar sus emblemas y escudos ${ }^{3}$ : podríamos pensar, por lo tanto, que es nombre muy apropiado para un rey. No obstante, el nombre de Oriol -único dato que se nos ofrece sobre él- no se corresponde con el de ninguno de los que gobernaron los diferentes reinos peninsulares durante el siglo XIII o las centurias anteriores.

Una búsqueda detallada de los términos «oriol» $\mathrm{y}$ «Oriol» en la base de datos del CORDE de la RAE ofrece resultados relevantes, tanto en el ámbito jurídico como en el literario. Están documentados al menos ocho casos diferentes de «Oriol» como nombre propio o apellido, recogidos todos ellos en actas notariales y otros documentos jurídicos del periodo medieval (fechados entre 1044 y 1400) . Todos ellos demuestran que

\footnotetext{
${ }^{2}$ Ibid., vv. 289-300.

${ }^{3}$ La simbología de los colores amarillo o dorado es universal; ambos se asocian al poder regio en culturas tan distanciadas como la europea o la asiática: «[...] Algo que potenciaba todavía más la sensación de intimidación [en la China Imperial] era el uso indiscriminado del amarillo de un dorado rojizo estrictamente reservado a la realeza» (Kassia St. Clair, Las vidas secretas del color, Barcelona, Ediciones Urano, 2017, p. 84).

${ }^{4}$ En una donación realizada en Alascor al monasterio de San Victorián (Pueyo de Araguás, Huesca), durante el reinado de Ramiro I de Aragón (1044), se menciona a un tal «Oriol Aracuz»: «[...] in uilla alascorr oriol aracuz [...]» (Eduardo Ibarra y Rodríguez, Documentos correspondientes al reinado de Ramiro I: desde MXXXIV hasta MLXIII años, Zaragoza, Imprenta Andrés Uriarte, 1904, p. 54). Otros casos destacados son el de «Alarico Oriol» en
} 
el nombre de Oriol era frecuente en el reino de Aragón durante la Edad Media, si bien en ningún caso es utilizado como nombre regio. Estos testimonios pertenecen a un periodo temporal muy estrecho (siglos XI-XII), que coincide con la formación y orígenes del reino de Aragón. Proceden de la misma zona, el área pirenaica aragonesa, en las inmediaciones de la población de $\mathrm{Jaca}^{5}$ (están relacionados con lugares de este entorno, como Santa Cruz de la Serós, Biescas, Villanúa, Atarés, Pueyo de Araguás o la propia villa de Jaca).

Uno de los lugares más destacados y conocidos de esta comarca de la Jacetania posee un nombre casi idéntico al de Oriol. Se trata de la peña Oroel (1769 m.), monte en el que se ambientan multitud de leyendas y que es muy visible desde la población de Jaca. A su sombra se encuentra el monasterio de San Juan de La Peña, fundamental en el desarrollo del reino medieval de Aragón. A pesar de que siempre resulta complejo y arriesgado tratar de analizar la etimología de topónimos tan antiguos como este, en este caso el nombre de Oroel parece estar relacionado con el aspecto que presenta este monte al atardecer, cuando inciden sobre él los rayos del ocaso y adquiere unas características -y muy llamativatonalidades dorada y rojiza. Algunas teorías consideran que el término está formado sobre la supuesta raíz prerromana $u r$-/or-, que es posible encontrar también en otros topónimos de montañas de aspecto dorado (como el Pico Urriellu, en Picos de Europa). Es una hipótesis nada segu$\mathrm{ra}$, que establece sus premisas en antiquísimas e inciertas raíces léxicas.

$1045(«[\ldots]$ et Galin azenari presbiter et Alarico oriol [...]», Ibarra, ed. cit., p. 65), «Oriol Asnar» en 1068 («[...] ego Oriol Asnar, frater de Castro Athares [...]»; José Salarrullana de Dios, Colección de documentos para el estudio de la historia de Aragón. Tomo III. Documentos correspondientes al reinado de Sancho Ramires (vol. II) (1063-1094), Zaragoza, M. Escar Tipógrafo, p. 57); «Oriol Sanz» en 1076 («[...] et sunt auditores Vita Ferruz et Oriol Sanz [...]»; ibid., p. 103). Es posible encontrar más ejemplos en: ibid., p. 157; ibid., p. 195; Dámaso Sangorrín y Diest-Garcés, El libro de la cadena del concejo de Jaca: documentos reales, episcopales y municipales de los siglos $X, X I, X I I, X I I I$ y XIV, Zaragoza, Imprenta de F. Martínez, 1921, p. 148; Antonio Ubieto Arteta, Cartulario de Albelda, Valencia, Gráficas Bautista, 1960, p. 106; Tomás Muñoz y Romero, Colección de fueros municipales y cartas pueblas de los reinos de Castilla, León, Corona de Aragón y Navarra, Madrid, Imprenta de José María Alonso, 1847, p. 479.

Es curioso el caso de un testamento de 1081, otorgado en el monasterio de San Juan de la Peña por un marido y una mujer llamados Aznar y «Blaskita», en el que ambos reparten sus bienes y deciden legar parte de ellos a dicho cenobio (y mencionan, de paso, términos que han de ser considerados ya como romances y no como latinos: «illos mulos, et kaballos, et equas, et bakas, et oues, et porkos»), por ser ella «filia de abbate Oriol» («[...] nos ego Açenare et uxor mea domina Blaskita [...] Similiter et illos mulos, et kaballos, et equas, et bakas, et oues, et porkos, qui tangunt ad illo defuncto totos sint de Sancto Ihoanne, simul cum illa kasa de Aransule quam afiliot ad me domina Blaskita filia de abbate Oriol [...]»; ibid., p. 153). Ambos son, asimismo, padres de «Oriol Açenariç» («[...] Oriol Açenariç meo filio [...]»; ibid., p. 154).

${ }^{5} \mathrm{La}$ acumulación de testimonios en tan estrecha franja territorial puede deberse a la existencia y conservación de una mayor cantidad de documentos notariales en el entorno, si bien es difícil de determinar sin disponer de más datos al respecto. 
En adición, otros consideran que esa misma raíz posee significados muy diferentes ('fuente de agua', 'elevación del terreno')

Creo que la etimología del término puede explicarse a partir de un proceso evolutivo muy similar al del nombre de Oriol, con el que se establecen paralelos evidentes: el característico color de esta «peña dorada» (en latín medieval: mons aureoli) parte del mismo término que el que sirve de raíz en el caso de Oriol (aureolus, -a, -um): aureoli $>$ oroli $>$ oroel. Y es muy significativo, porque Oriol y Oroel comparten de esta manera la misma raíz y carga semántica. Cuatro documentos diferentes del siglo XI (entre 1066 y 1085) validan este origen, pues recogen el término intermedio que se generó durante el proceso de evolución etimológica ${ }^{7}$, justo antes de que se produjese la metátesis del último fonema consonántico $(l i>e l)$. Todos ellos son documentos notariales que atestiguan transacciones y cesiones de terrenos, y se refieren a este lugar como el monte «Oroli», relacionándolo con el cercano monasterio de San Juan de la Peña. Documentan la fase intermedia (oroli) del mencionado proceso de evolución fonética aureoli $>$ oroli $>$ oroel, que de este modo quedaría perfectamente explicado a partir del color dorado del monte ${ }^{8}$.

OROPÉNDOLA, ÁGUILA Y REYEZUELO. LAS AVES COMO SÍMBOLOS DEL PODER

Una vez establecido el origen y significado del nombre Oriol, es necesario determinar con qué especie de ave se puede identificar al rey del poema Elena y María. Diversas derivaciones de la forma latina aureolus han evolucionado en las lenguas europeas en términos muy similares

${ }^{6}$ «En cuanto al origen de Urriellu y sus congéneres, sigo pensando [...] que es prerromano y que suponen una forma básica orro, alternante de oro, coincidente con el griego oros; monte, que precisamente nos sirve para formar orografia, oronimia y otras voces cultas de la lengua común» (José Manuel González, «Temas de toponimia asturiana», Archivum: Revista de la Facultad de Filología, 21 (1971), pp. 121-140, p. 129).

${ }^{7}$ «[...] ad sanctum Iohanem de Oroli que est in Aragon unum monasterium sanctus Ihoannes de la Pinna [...]» (Salarrullana, ed. cit., p. 34); «[...] in Sancti Ihoannis de Oroli de Aragone [...]» (ibid., p. 75); «[...] Sancti Joannis de Oroli, que est in terra quae vocatur Aragone [...]» (ibid., p. 88); «[...] in monasterio Sancti Joannis Baptistae, qui situs est in monte qui apellatur Oroli [...]» (ibid., p. 175). Estos testimonios demuestran que el uso del genitivo (aureoli/oroli) en este topónimo parece que ya se solapaba durante la Edad Media con la utilización de la preposición de con esa misma función.

${ }^{8}$ No es el único caso en la toponimia española en el que un monte de coloración dorada sirve de inspiración para denominar a dicho lugar: Orihuela/Oriola (Alicante) se encuentra también rodeada por elevaciones rocosas que adquieren tonalidades doradas bajo la luz apropiada. Emili Casanova establece que la etimología se explica a partir de la evolución de aureola, diminutivo de aurea ('dorada'), que él considera que se podría referir a las minas de oro que existían por la zona durante la Antigüedad (Emili Casanova, "Comunidad Valenciana», en Toponimia hispánica. Origen y evolución de nuestros topónimos más importantes, Valencia, Denes, 2011, pp. 257-292). Creo que el proceso de evolución se explica, del mismo modo que en el caso del monte Oroel, a partir del color de las peñas que rodean al municipio alicantino, que adquieren una llamativa tonalidad dorada al caer el sol. 
para hacer referencia a una de las aves más vistosas de la fauna ibérica: la oropéndola europea (Oriolus oriolus). Es posible comprobarlo en el nombre que posee en los romances peninsulares (oriol, en catalán; ouriolo, en gallego), pero también en otras lenguas no derivadas del latín (es el caso de las formas golden oriole, en inglés, y de urretxoria, en eusquera, que sigue manteniendo en su raíz urre- la referencia al color dorado). El plumaje de color amarillo dorado, muy brillante, es la característica más llamativa de esta especie9.

La oropéndola ocupa hábitats arbolados o forestales. No obstante, prefiere zonas de ribera y sotos de ríos. Es habitual escuchar su aflautado canto en estos lugares, donde se alterna con el del ruiseñor (Luscinia megarhynchos) durante la primavera y el verano. Tanto el canto del ruiseñor como las inmediaciones de corrientes naturales de agua han sido durante siglos lugares comunes en las descripciones literarias -populares o cultas- de los encuentros entre amantes. La propia estación primaveral, momento en que es más fácil detectar a la esquiva oropéndola, es el tiempo más adecuado para el amor. De hecho, el rey Oriol de Elena y María es juez especialista en este tipo de asuntos («Este rey e emperador/nunca julga senon de amor $\rangle^{10}$ ) y gobierna una corte en la que, de nuevo, no se realiza otra actividad «senon cantar sienpre de amor» ${ }^{11}$. No resultaría extraño, por lo tanto, que el nombre del soberano pudiese hacer referencia a la oropéndola, a la que se le concedería un uso simbólico único en la tradición literaria hispánica: sería el juez especializado en cuestiones de amor. La belleza de su canto, desde luego, no se aleja de la que posee el del ruiseñor, asociado en el medio natural a los mismos hábitats y estaciones que la oropéndola y cargado de connotaciones amorosas en el ámbito literario. De hecho, ambas especies se entrecruzan con cierta frecuencia en fragmentos literarios posteriores a la Edad Media precisamente por estas similitudes ecológicas y etológicas ${ }^{12}$. Su

${ }^{9} \mathrm{La}$ oropéndola es un ave de pequeño tamaño (sus proporciones se asemejan a las del mirlo, Turdus merula) que habita en zonas forestales. Solo el macho tiene un plumaje de color dorado intenso, pues el de la hembra posee tonos más apagados. Es una especie estival, que habita en la Península Ibérica y Europa entre los meses de abril y septiembre. Pasa el resto del año en las regiones del África subsahariana.

${ }^{10}$ Menéndez Pidal, art. cit., vv. 287-288.

${ }^{11}$ Ibid., v. 296.

${ }^{12}$ Lope de Vega menciona esta pareja de aves en La Arcadia: «Llevaba Danteo su flauta [...], un tamboril destemplado a cuyo son cantaba, no las grandes vitorias de los dioses ni las transformaciones de Júpiter, sino las fábulas y apólogos de las ranas y los gallos, cantando los amores del cuervo y la paloma, lo que le dijo el ruiseñor a la oropéndola [...]» (Félix Lope de Vega y Carpio, La Arcadia, Edwin S. Morby, ed., Madrid, Castalia, 1975, p. 148). También se refiere a ella en Pastores de Belén: «Yo un nido de una pájara, en cogiéndola, / que estuve entre unos olmos acechándola, / y si no es ruiseñor, será oropéndola» (Félix Lope de Vega y Carpio, Pastores de Belén, prosas y versos divinos, Antonio Carreño (ed.), Barcelona, PPU, 1991, p. 486). Incluso, Ortega y Gasset identifica las similitudes que existen en el canto de ambas especies: «La oropéndola da un denso grito de su garganta, tan musical que parece una esquirla arrancada al canto del ruiseñor, un son breve y súbito que un instante llena por completo el 
vistoso plumaje dorado habría sido el elemento en el que se habría fijado el poeta para otorgarle la categoría regia sobre el resto de aves ribereñas, al menos en materia amatoria.

La inexistencia de una tradición que respalde esta hipótesis es, ciertamente, el principal inconveniente que permite aceptar dicha identificación. A pesar de que sería posible que el rey Oriol fuese una oropéndola, por su color y coincidencia total de nombre, lo cierto es que no existe ningún texto ni representación pictórica de la tradición europea en el que la oropéndola ostente la categoría de reina de todas las aves. Dicha responsabilidad ha recaído siempre sobre otras especies, con cualidades más apropiadas para ejercer el poder (como la posesión de una gran fuerza o de una inmensa envergadura) que la oropéndola, cuya virtud más destacada es tan solo su color dorado.

Habitualmente, es el águila real ${ }^{13}$ (Aquila chrysaetos) el ave que sirve como símbolo o emblema de la monarquía ${ }^{14}$, por su evidente poderío físico, por su apariencia esbelta y por ocupar como depredador la cima de la pirámide trófica. En el ámbito hispánico, son bien conocidos los casos del águila de San Juan (utilizada en primer lugar por Isabel I de Castilla y, más tarde, también por su marido Fernando II de Aragón) o del águila bicéfala (blasón de la dinastía de los Habsburgo). No obstante, el uso del águila como símbolo de poder llega mucho más atrás en el tiempo. No conviene olvidar el concepto romano de imperium: era la capacidad de mando, ejecución y poder militar que ejercían sobre la ciudadanía ciertos cargos públicos de relevancia (entre otros: pretores, cónsules o dictadores). Dicho concepto era representado precisamente mediante un bastón coronado con la figura de un águila, que acompañaba al funcionario en cuestión. Más conocida aún es la utilización de la efigie de esta rapaz como emblema de las disciplinadas y temibles legiones romanas, que eran guiadas en combate por el estandarte formado por un águila de oro, que portaba con orgullo el aquilifer, soldado especializado en tal cometido ${ }^{15}$.

volumen perceptible del bosque» (José Ortega y Gasset, Meditaciones del Quijote, Julián Marías (ed.), Madrid, Cátedra, 1990, p. 107).

${ }^{13}$ También el águila imperial ibérica (Aquila adalberti) o el águila imperial oriental (Aquila heliaca) han sido utilizadas en los mismos contextos simbólicos que el águila real.

${ }^{14} \mathrm{El}$ águila, como ave de mayor jerarquía, es el ave adecuada para servir (y representar) al mayor de los dioses griegos: Zeus. Por ello, «Cuando Zeus toma sus disposiciones para combatir a los titanes, el águila le trae su dardo, y es por este motivo por lo que Zeus adoptó el águila como emblema guerrero» (Angelo de Gubernatis, Mitología Zoológica. Las leyendas animales. Los animales del aire, Barcelona, José J. de Olañeta Editor, 2002, p. 28). Ello explica la proliferación del uso de la efigie de esta rapaz en el ámbito militar y político romano, entre otros casos representativos.

${ }^{15}$ Tal relevancia poseía dicho estandarte que era guardado con los mayores honores dentro del campamento y defendido en batalla hasta las últimas consecuencias: su pérdida en favor del enemigo era considerada el mayor deshonor que podía experimentar una legión romana. Era custodiado en el «aedes signorum», el 'santuario del pretorio donde se guardaban los estandartes de la legión cuando estaba en campaña, a saber: el aquila, los signa, los vexilla y las 
A pesar de todo lo anterior, existe una diminuta ave que en ocasiones también ha representado el poder en ámbitos más próximos al folklore y las tradiciones populares. Se trata del reyezuelo ${ }^{16}$, que debe su nombre a las plumas doradas -a modo de «corona»-que existen en la zona superior de su cabeza. Esta característica es la que ha propiciado que el reyezuelo haya sido identificado como símbolo regio en algunas composiciones de la tradición oral europea ${ }^{17}$. A diferencia del águila, el reyezuelo es siempre representación de un poder temporal y limitado (en el tiempo y en su alcance), que es arrebatado a su dueño legítimo ${ }^{18}$. Por lo tanto, jamás puede ejercer soberanía sobre el resto de aves.

Es frecuente que se asocie y combine a estas dos aves tan dispares (reyezuelo y águila) en multitud de leyendas que cuentan la disputa que se dio entre ambas por gobernar sobre todos sus congéneres, dado que las dos especies estarían en principio legitimadas para ello. Aunque el contenido y desarrollo de estas historias son muy variados, lo habitual es que se determine al vencedor de la contienda mediante una competición de vuelo. El ave que consiga ascender hasta un punto más elevado será la que obtenga la victoria ${ }^{19}$.

imagines [...]' (s. v. aedes, José María Sanz López, Voces militares de las legiones romanas, Madrid, Ediciones Áltera, 2016).

${ }^{16}$ Existen dos especies de apariencia prácticamente idéntica: el reyezuelo sencillo (Regulus regulus) y el reyezuelo listado (Regulus ignicapilla). Ambas son unas de las aves más pequeñas que residen en Europa -no superan los nueve centímetros de tamaño-.

${ }^{17}$ La caza y muerte del reyezuelo ha sido un ejercicio absolutamente prohibido para la mentalidad colectiva desde tiempos inmemoriales, pues se creía que llevaría a sufrir grandes penalidades a aquel que la causase. Esta misma conciencia es detectable en una de las obras en prosa del universo artúrico dedicadas a Merlín, compuesta a mediados del siglo xv, en la que «los caballeros de la Tabla Redonda parten a vengar la muerte del reyezuelo» (Jean-Loïc Le Quellec, «Le roi des oiseaux: Rabertaud, Sibbus, Rokh et Garuda», Bulletin de La Société de Mythologie Française, 181-182 (1996), pp. 81-108, p. 91). A pesar de ello, la caza ritual del reyezuelo ha sido una tradición importante en numerosas zonas rurales de Francia y España (en comarcas de Lugo, Vic, Carcassonne, Brest o La Ciotat). Las particularidades varían según el lugar, pero lo general es que durante el día de año nuevo -o en fechas cercanas- un reyezuelo fuese capturado en el bosque para marcar el tránsito hacia el nuevo año, elegir al nuevo alcalde o simbolizar la sumisión del pueblo a la autoridad local. Generalmente era transportado hasta un lugar determinado en grandes carretas o jaulas (para exagerar su diminuto tamaño) y que, tras la realización del rito en cuestión, fuese liberado. Una explicación completa de todas estas tradiciones puede ser consultada en Ignacio Abella, Aves familiares. Vida y leyenda, Bilbao, Libros del Jata, 2017; Le Quellec, art. cit.

${ }^{18}$ Tanto es así que el término reyezuelo es utilizado en castellano de manera habitual en este mismo sentido para hacer referencia, precisamente, a alguien que se otorga a sí mismo un poder regio sin poseer demasiada legitimación para ello. También puede describir a pequeñas élites locales que actúan con categoría de rey, sin serlo realmente. Incorpora una connotación negativa que realza esta ilegitimidad o poco poder efectivo de quien recibe dicho calificativo: «El moro había amado en sus lucidos abriles a una mora Ramada Zelindaja, hija de un reyezuelo de Andalucía [...]» (Mariano José de Larra, El doncel de don Enrique el Doliente, Barcelona, Linkgua Digital, 2016, p. 253).

${ }^{19}$ Sucede que el reyezuelo, que evidentemente no posee unas cualidades fisiológicas tan formidables como las del águila, se sirve de su astucia para engancharse a su espalda sin que la rapaz pueda advertirlo. Cuando ya se encuentran a gran altitud, el reyezuelo aprovecha el desgaste sufrido por el águila para, entonces sí, emprender el vuelo e impulsarse más alto que 
En suma, este recorrido permite obtener las siguientes conclusiones sobre la identidad del rey Oriol: en principio, dicho personaje no puede cobrar la forma de una oropéndola porque esta especie no es nunca símbolo de poder; tampoco se trata de un reyezuelo, tal y como acabamos de analizar. El soberano de todas las aves ha sido, desde la Antigüedad, el águila.

\section{EL FALCÓN ORIOL, REY DE TODAS LAS AVES}

Estos datos podrían conducirnos, por pura lógica, a identificar al rey Oriol de Elena y María con alguna de las especies de águilas existentes en el continente europeo. Sin embargo, existen al menos otros dos textos medievales castellanos en los que es utilizado el término oriol como adjetivo calificativo (con el significado etimológico ya estudiado de 'dorado', y no como nombre propio de persona) que permiten descifrar qué ave en concreto podría ser este rey.

Destacan las menciones que el Calila e Dimna (1251) y el Libro del cavallero Zifar (c. 1300) realizan de un ave rapaz hasta ahora no identificada, que lleva el mismo nombre que el soberano de Elena y María y a la que ambos textos se refieren como «falcón oriol» (literalmente, 'halcón dorado'). Detengámonos, en primer lugar, en el fragmento del Calila e Dimna en que aparece este supuesto falcónido. Está situado al final del capítulo III de la obra («Del león et del buey»), en el exemplum de «Los dos ánades y el galápago» que está inserto, a su vez, en otro exemplum, el de «Los tittuy y el mayordomo del mar» ${ }^{20}$ (esta estructura

ella, por lo que consigue finalmente ser coronado como rey de todas las aves; en Abella, op. cit., pp. 251-253.

${ }^{20}$ Calila e Dimna, Juan Manuel Cacho Blecua y María Jesús Lacarra (eds.), Madrid, Castalia, 1984, p. 164.

Estos «tittuy», por el hábitat que ocupan y cómo son descritos, son aves limícolas -aves acuáticas que habitan a la orilla del mar-. En esta edición son identificados con el archibebe fino (Tringa stagnatilis), según se dice, porque suelen invernar «en los alrededores de aguas interiores y marismas» y «suele criar, a veces en pequeños grupos, en orillas de lagos con pasto y llanuras pantanosas» (ibid., p. 164). Sin embargo, tal identificación no es exacta: tal y como aparece en esta misma cita y como refieren las guías de aves más destacadas, el archibebe fino no cría a la orilla del mar (que es lo que describe el texto del Calila), sino en «ciénagas y marjales herbosos de estepas y otras tierras bajas» (Lars Svensson, K. Mullarney y Dan Zetterström, Guía de aves. España, Europa y región mediterránea, Barcelona, Ediciones Omega, 2010 , p. 156). Únicamente se acerca al litoral durante el invierno, cuando no se encuentra en época reproductiva. Todo esto hace imposible que el «tittuy» sea el archibebe fino, que es, por otro lado, una especie muy escasa en Europa. Los pocos datos que aporta el texto hacen difícil la identificación de esta limícola. Probablemente se trate de un tipo de chorlito o chorlitejo, pues el texto árabe así lo denomina («A quien desdeña al enemigo le ocurre lo que le ocurrió a la marea con el chorlito»; Abdalá Benalmocaffa, Calila y Dimna, Marcelino Villegas, trad., Madrid, Alianza Editorial, 2008, p. 144). Las zonas de cría de todas las especies de chorlito se encuentran en las costas del norte de Europa, lejos de Oriente Medio y Arabia (lugares de origen del texto original), por lo que este aspecto difiere con lo que se dice en el texto. Parece mucho más acertado pensar que se trate de un chorlitejo, sea el chorlitejo grande (Charadrius 
de subordinación es característica de la obra). Los tittuy, pequeñas aves limícolas que crían en la orilla del mar, lamentan la pérdida de su nido, que les ha sido arrebatado por el «mayordomo de la mar» (la marea y su fuerza destructora). Deciden buscar ayuda en una asamblea de aves, que determina que la mejor opción consiste en solicitar al señor de todas ellas, el falcón oriol («El rey de todas nos las aves es el falcón oriol. $[\ldots]$ Tú eres nuestro señor et nuestro rey $\left.[\ldots] »^{21}\right)$, que intervenga para solucionar el problema:

Dixo: - Ayuntémosnos et vayámosnos a las otras aves, et digámosgelo. Et toviéronlo por bien, et fuéronse a las otras aves et dixéronles lo que acaesçiera, et aperçibiéronlas porque les acaesçería otro tal commo a él acaesçiera.

Dixéronles: -Así es commo vós dezides, mas ¿qué mal podemos nós fazer a la mar et al su mayordomo?

Dixéronles: - El rey de todas nos las aves es el falcón oriol. Llamémoslo fasta que se nos muestre.

Et fiziéronlo así, et mostróseles et díxoles: —¿Qué cosa vos ayuntó o por qué me llamastes?

Dixéronle ellas lo que les acaesçiera por la mar et por su mayordomo.

Dixéronle: -Tú eres nuestro señor et nuestro rey, et el poder que tú has creemos que es más fuerte que el mayordomo de la mar. Pues vete para él et ruégale que nos emiende el tuerto que nos fizo. Et si lo fiziere, [bien], et si non, aparejarnos hemos a lidiar con él. Quando lo sopo el mayordomo de la mar, entendió su flaqueza apos la fortaleza del falcón oriol et tornó los pollos del tituy ${ }^{22}$.

Es muy notable la identificación unánime y decidida que realizan todas las aves de aquel que reina sobre todas ellas, este falcón oriol. Es descrito como un ave temible, capaz incluso de superar a este «mayordomo de la mar», que pronto advierte su debilidad frente a esta poderosa ave y decide devolver sus pollos a los tittuy («Quando lo sopo el mayordomo de la mar, entendió su flaqueza apos la fortaleza del falcón oriol et tornó los pollos del tituy» ${ }^{23}$ ). A priori, es difícil pensar de qué modo podría un halcón atemorizar a la marea (que no es un ser vivo), pero comienza a cobrar sentido si pensamos en ello dentro de un plano alegórico y simbólico. Con todo, los datos a los que me he referido no son aún del todo suficientes para obtener una identificación precisa.

El fragmento del Zifar contribuirá a desvelar la identidad de este falcón oriol. Pertenece, en principio, a una ambientación de carácter más

hiaticula) o el chorlitejo patinegro (Charadrius alexandrinus). De entre todos los chorlitejos, son los que más habitualmente crían en las orillas marinas en zonas compatibles con la narración del Calila e Dimna (Svensson et al., op. cit., pp. 138 y 140).

${ }^{21}$ Ibid., p. 166.

${ }^{22}$ Calila e Dimna, ed. cit., pp. 166-167.

${ }^{23}$ Ibid., p. 167. 
realista y menos metafórica que el pasaje del Calila en que es mencionada esta rapaz. Esta misteriosa ave es nombrada de pasada, inserta en una de las descripciones de la corte del emperador, que posee un azor de prodigiosas características, muy bello y de gran tamaño. Tan portentoso es que ni siquiera se asusta de las rapaces más poderosas:

E otro día en la mañana fue a caça con el açor en la mano e con el alano, que traía en la trayella atado a la su çinta. E quando llegó a la ribera, nunca lançó el açor que errasse: lançó tan bien a las ánades como a las garças e ahuestores e a las autardas, e non le escapava ninguna presión por grande que fuese. E aun dexava la presión maguer viese las águilas, ante fuían de él como si fuese señor de todas las aves. E aun el falcón oriol, que paresció ý en ese tiempo, non lo osó esperar e fuese desterrado ${ }^{24}$.

Ambos textos coinciden en presentar al falcón oriol como señor de todas las aves ${ }^{25}$, en especial el testimonio del Calila e Dimna. En el fragmento del Zifar esta soberanía del falcón oriol se advierte de manera algo más tamizada. Una gradación ascendente permite comprender la excepcionalidad del azor del emperador: atemoriza a todas las aves, primero a las presas habituales de las cacerías (ánades, garzas, avetoros, etc.), después a las águilas (que «ante fuían de él como si fuese señor de todas las aves $\rangle^{26}$ ) y, por último, al falcón oriol, que por lo tanto ostenta una categoría superior sobre el resto de aves enunciadas (a pesar de que también él huye del azor del emperador); su jerarquía es más elevada incluso que la del águila, tradicional símbolo de poder y realeza. El problema es que ningún halcón de los muchos que utilizaban para cazar los nobles medievales recibía el nombre de falcón oriol. Halconeros y cetreros de la época diferenciaban entre seis tipos fundamentales de halcones: neblí, baharí (en el que se incluía al halcón tagarote), gerifalte, sacre, borni y alfaneque (estos dos últimos solían ser también denominados laneros $)^{27}$. No existe ninguna mención en los tratados de cetrería

\footnotetext{
${ }^{24}$ Libro del caballero Zifar, Joaquín González Muela (ed.), Madrid, Castalia, 1990, p. 396.

${ }^{25}$ Joaquín González Muela, editor del Zifar, no da noticia de la naturaleza del falcón oriol y lo identifica como una simple «águila, ave de rapiña» (ibid., p. 396). Ofrece una referencia errónea adicional, pues duda si el falcón oriol puede ser la misma rapaz que avistó Marco Polo en la ciudad de Kermán (Persia, en el actual Irán): esta ave no puede ser el falcón oriol porque es descrita como un falcónido de tamaño inferior al halcón peregrino (Falco peregrinus), cuya característica más singular es el plumaje de color rojo en el pecho y bajo la cola, así como la rapidez de su vuelo (Marco Polo, Viajes, María de Cardona y Suzanne Dobelmann (trads.), Alicante, Biblioteca Virtual Miguel de Cervantes, 1999, cap. 35. En línea: $<$ http://www.cervantesvirtual.com/nd/ark:/59851/bmcjw896> [consulta: 20/03/2019]). Ninguna de estas cualidades es propia del falcón oriol, tal y como será analizado más adelante.

${ }^{26}$ Libro del caballero Zifar, ed. cit., p. 396.

${ }^{27}$ Esta división de las especies de halcones aparece en multitud de tratados de cetrería castellanos de la Edad Media. Es el caso de los más importantes: De arte venandi cum avibus (Federico II de Hohenstaufen) el Libro de la caza de las aves (Pedro López de Ayala) y el Libro de la caça (Don Juan Manuel). Ninguno de ellos hace referencia al falcón oriol. Ver en
} 
medieval a este supuesto falcón oriol. Así, es evidente que hemos de situarnos no en un ambiente real, el de la cetrería, sino en el mundo de las tradiciones y los mitos. El falcón oriol no puede ser identificado con ninguna de las anteriores especies de halcones, ni tampoco con ninguna de las conocidas en la actualidad; ningún falcónido posee una tonalidad en la que predominen los tonos amarillos o dorados en tal grado como para otorgarle este apelativo ${ }^{28}$. Tampoco es un águila corriente, pues en dicho caso sería recibiría el nombre de «águila oriol» ${ }^{29}$, y no se ensalzaría su morfología de falcónido como un rasgo particular.

De hecho, el halcón no ha sido nunca utilizado como símbolo de poder regio o imperial. En las literaturas griega y romana (y, por herencia, en la tradición occidental moderna), el halcón era un símbolo guerrero muy importante $\mathrm{e}^{30}$. La fuerza y la velocidad son sus características fundamentales, pero también lo es la astucia ${ }^{31}$. Todas ellas son compartidas por los halcones y las águilas. Con todo, el halcón simboliza más al guerrero valiente y activo que al soberano fuerte y tranquilo. El halcón

Federico II de Hohenstaufen, El arte de cetrería. De arte venandi cum avibus. Tomo I (Libro I - Libro II), C. A. Wood, F. M. Fyfe y J. M. Sánchez (eds. y trad.), Madrid, Cairel Ediciones, 2004; Pedro López de Ayala, Libro de la caza de las aves, José Fradejas Lebrero y José Manuel Fradejas Rueda (eds.), Madrid, Castalia, 2016; Don Juan Manuel, Obras completas, Carlos Alvar Ezquerra y Sarah Finci (eds.), Madrid, Biblioteca Castro, 2007, pp. 301-372.

${ }^{28}$ Los halcones más valorados eran el neblí y el gerifalte: el primero, por su habilidad y rapidez en vuelo; el segundo, por su corpulencia y fuerza (no en vano, el halcón gerifalte es el halcón de mayor tamaño). Ninguna de estas dos especies posee tonos dorados en el plumaje, en el que predominan los tonos ocres y pardos. El halcón sacre es el único que se acerca más a las tonalidades amarillentas en su plumaje, pero no hay razón para convertirlo en señor de todas las aves cuando ni siquiera los cetreros medievales consideraban que fuese el mejor de los halcones. Ahora quedará demostrado que ninguno de estos halcones puede ser el falcón oriol.

${ }^{29}$ Existen representaciones de águilas doradas en la tradición europea, además de las ya mencionadas águilas de las legiones romanas. Una de las más conocidas es el Águila de SaintDenis o Águila de Suger, conservada en el Museo del Louvre (París), con número de inventario MR 422. Esta pieza está formada por un ánfora de pórfido de la Roma imperial, que fue decorado con la efigie de un águila de plata dorada durante el siglo XII por mandato del abad Suger (1122-1151).

La diferencia que existe entre este testimonio y los del falcón oriol es que se trata, simplemente, de la representación de la efigie de un águila real. El caso de las representaciones del falcón oriol no es equivalente, porque todas ellas se refieren a un animal que no es un halcón, sino el ave fénix. En línea: < https://www.louvre.fr/oeuvre-notices/vase-de-porphyre-aigle-desuger> [consulta: 20/03/2019].

${ }^{30}$ «Como el águila, el hierax ['halcón', en griego] y su homólogo latino el accipiter son rapaces predadoras y se caracterizan por su valor guerrero. Esta pequeña rapaz sirve como comparación para los guerreros valerosos de los poemas homéricos. Patroclo cae sobre los troyanos como un halcón sobre las grajillas o los gorriones [Il. 16.581-585]. En el canto siguiente [...], Héctor y Aquiles son comparados a pequeñas rapaces, precisamente con halcones atemorizando a grajillas y gorriones [Il. 17.753-759]» (Trad. propia de: Hélène Normand, Les rapaces dans les mondes grec et romain. Catégorisation, représentations culturelles et pratiques, Burdeos, Ausonius, 2015, p. 378).

${ }^{31}$ «Si bien esta pequeña rapaz [el halcón] es admirada por su fuerza o su velocidad, Quinto de Esmirna ensalzará asimismo su astucia» (Trad. propia de: ibid., p. 379). El pequeño tamaño de los halcones frente a las águilas sirve para ponderar aún más su gran fuerza, contenida en un cuerpo de proporciones más limitadas. 
posee en la tradición literaria un comportamiento más temerario, iracundo, imprudente y violento ${ }^{32}$ : son rasgos inapropiados en un rey. Todo esto explica la utilización de cada una de estas rapaces como símbolos de virtudes semejantes, pero no aplicables de un mismo modo. El halcón puede ser el guerrero o el héroe; el águila es el rey.

A pesar de su nombre, el falcón oriol no encaja en estas características que, según acabamos de analizar, la tradición atribuye a los falcónidos. En los dos fragmentos en los que aparece (Calila e Dimna y Libro del cavallero Zifar) se muestra como un ave más mesurada, tranquila y sabia que sus supuestos congéneres, más nerviosos e impetuosos. En este sentido, posee un comportamiento más semejante al del águila. Sin embargo, ni puede ser halcón (por esta diferencia de comportamiento y porque el halcón jamás es símbolo de poder regio, pues no posee tal jerarquía) ni puede ser águila (porque es claramente diferenciado de las águilas en los textos y recibe el nombre de «falcón»). Podría objetarse que precisamente las denominaciones científica e inglesa del águila real (Aquila chrysaetos y Golden eagle, en cada caso) significan, de manera literal, 'águila dorada': en realidad, el plumaje del águila real es mayoritariamente pardo, más bien oscuro. Solo ciertas zonas de su plumaje poseen tonalidades cercanas al color dorado, que pueden intensificarse a simple vista según se produzca la incidencia de la luz sobre ellas ${ }^{33}$. Falcón oriol no puede ser entendido como un nombre alternativo para esta especie de rapaz ${ }^{34}$ : los argumentos que acabo de exponer, sumados a las particularidades morfológicas que presenta el falcón oriol en sus representaciones iconográficas (que serán analizadas más adelante) evidencian que se trata de un ave particular y específica, perfectamente diferenciada de cualquier especie de ave de presa existente. El sustantivo 'falcón' del término no indica que esta ave sea un halcón en sentido estricto, tan solo que posee condición de ave de presa y una morfología próxima a la de las grandes rapaces y los falconiformes.

¿De qué ave se trata, entonces? Tal y como ahora quedará demostrado, se trata de un ave mitológica, en cuyos orígenes se entrecruzan culturas y tradiciones muy variadas y que posee unas características prácticamente

${ }^{32}$ ibid., p. 381

33 «Marrón bastante oscura en todos los plumajes, con la nuca pardo amarillenta o pardo rojiza clara [...]» Svensson et al., op. cit., p. 94); «El adulto luce coloración general parda muy oscura, con tonos más dorados en las alas, la nuca y el cuello» (s.v. águila real, Sociedad Española de Ornitología, Guía de las aves de España, 2008. En línea: <https://www.seo.org/ ave/aguila-real/> [consulta: 21/03/2019]).

${ }^{34}$ Los autores medievales castellanos diferenciaban sin dificultad entre 'águila' y 'halcón', tal y como demuestran las incontables menciones del periodo a cada una de estas rapaces (s. v. águila, falcón, RAE: Banco de datos CORDE, Corpus diacrónico del español. En línea: $<$ http://www.rae.es> [consulta: 21/03/2019]). No es de extrañar, dado que la cetrería era uno de los pasatiempos más extendidos entre la nobleza de la Edad Media. 
idénticas a las que se atribuyen al falcón oriol: es el ave fénix, presentada a través de un nombre que era desconocido hasta el momento.

\section{EL FÉNIX O FALCÓN ORIOL, SOBERANO DE TODAS LAS AVES}

El ave fénix ${ }^{35}$ es, quizás, una de las criaturas mitológicas más conocidas. Su aspecto, características y simbología varían notablemente en las diferentes tradiciones en que aparece, aunque existen puntos en común muy significativos. Coinciden todas ellas en su inmortalidad (es devorado por el fuego cada quinientos años, para después volver a nacer a partir de sus propias cenizas) y su unicidad (pues existe un único ejemplar de fénix en todo el mundo). Se le suele atribuir la soberanía sobre todas las aves.

El origen del mito parece situarse en el Anti-

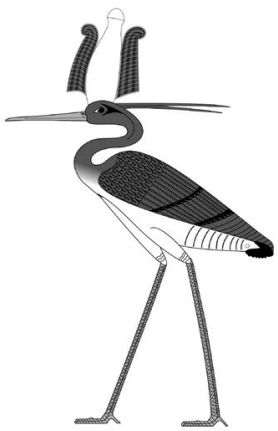

Figura 1: Bennu egipcio guo Egipto, donde era conocido como Bennu (Fig. ${ }^{36}$ ). Su aspecto difiere en esta cultura de las representaciones occidentales: presenta la forma de la lavandera boyera (Motacilla flava), la garza imperial (Ardea purpurea) o el flamenco (Phoenicopterus roseus). Por su etología y hábitos vitales, todas estas aves estaban asociadas a las crecidas periódicas del río Nilo, imprescindibles en la cultura del Antiguo Egipto para garantizar una producción de alimentos suficiente a la población. Se relacionaba con el culto al Sol (y al dios Ra, del que era considerado $b a$ o espíritu) y la ciudad de Heliópo$\operatorname{lis}^{37}$, una de las más importantes del Antiguo Egipto. Era asimismo símbolo de Osiris, el dios egipcio de la resurrección y de las crecidas del Nilo.

En la cultura egipcia es representado, por lo tanto, mediante la efigie de aves asociadas a ambientes fluviales, por la importancia que los ríos desempeñaban en los ciclos anuales de dicha civilización. Es descrita como un ave de colores dorados, rojos y púrpuras. El púrpura ha

${ }^{35}$ El término castellano fénix procede del lat. phoenix, -icis; y este a su vez del gr. $\varphi$ oĩvi $\xi$ (phoînix, -ikos). S. v. fénix, DRAE.

${ }^{36}$ Representación realizada por C Jeff Dahl. En línea: < https://en.wikipedia.org/wiki/Bennu\#/media/File:Bennu_bird.svg $>$.

${ }^{37}$ «[...] Estas aves depositaban sus huevos sobre la tierra egipcia, y los habitantes de Egipto pensaron que los polluelos nacían de forma espontánea, hecho que se puso en paralelo con el sol. Por si todo esto fuera poco, las garzas surcan los cielos al amanecer, lo que llevó a relacionarlo con el aspecto que tomaba el sol y, por extensión, el difunto, en la mañana, por lo que se hizo protector de los difuntos, fundiéndose al ciclo osiríaco. Una de las leyendas nacidas en la ciudad egipcia de Heliópolis, cuenta que el ave se había posado sobre la colina primordial y se había hecho responsable del cuidado del huevo de donde surgió el Sol. Debido a sus costumbres, fue considerada símbolo de la mañana (cuando aparecía en las orillas del río) y de la regeneración (por su función de ave migratoria que reaparece, que renace, que se renueva, periódicamente). Estos conceptos tuvieron su origen en la ciudad de Heliópolis» (s. v. 'Bennu': Elisa Castel, Gran diccionario mitología egipcia, Madrid, Editorial Aldebarán, 2002). 
estado vinculado al poder desde la Antigüedad: «En la Edad Media era un término identificado con el poder, con la excelencia social y de alto valor simbólico» ${ }^{38}$. No es casual que el fénix, soberano de todas las aves, posea entre las tonalidades de su plumaje este color reservado a emperadores y reyes. Incluso, parece que el propio nombre de fénix deba su origen a este hecho, pues el adjetivo latino phoeniceus es el que describe la púrpura propia de Fenicia, próxima a una tonalidad roja brillante ${ }^{39}$. Suele plantear confusas identificaciones durante el periodo medieval: puede hacer referencia al color del mismo nombre, pero también a otras tonalidades de rojo, carmesí, verde o azul ${ }^{40}$.

Otra de las características más habituales del aspecto del fénix es la cresta que le sale de la nuca (que indica que adoptó su morfología muy probablemente a partir de la propia de la garza imperial, única de las tres especies mencionadas que posee este rasgo). Esta ave fue adaptada rápidamente a las culturas griega y latina, en las que modifica su aspecto para semejarse más a la familia de las rapaces ${ }^{41}$. Es mencionada por primera vez por Heródoto, que advierte sobre el origen egipcio del mito y su conexión con Heliópolis (probablemente conoció estos datos de primera mano durante su viaje a aquella zona) y Arabia. Plinio el Viejo (Hist. natural, X, 2, 2) y Eliano (De natura animalium, VI, 58) describen asimismo al ave. «También aluden al fénix: Marcial (V, 7); Estacio (Silvas, 2, 4); Ovidio (Met., 15, 282); Tácito (Annales, 6, 28)» $\rangle^{42}$.

Antes de analizar la descripción de Heródoto, conviene saber que este autor le atribuye al fénix una morfología propia de las rapaces («su mote y figura son muy parecidas a las del águila» ${ }^{43}$ ). Este notorio cam-

${ }^{38}$ Laura Rodríguez Peinado, «Púrpura. Materialidad y simbolismo en la Edad Media», Anales de Historia del Arte, n. ${ }^{\circ}$ 24, n. ${ }^{\circ}$ esp. noviembre (2014), pp. 471-495; p. 472.

${ }^{39}$ Phoeniceus, - $a$, -um: 'de color rojo brillante [como la púrpura de Fenicia]' (s. v. phoeniceus, Nuevo diccionario etimológico Latín-Español y de las voces derivadas, Bilbao, Universidad de Deusto, 2013). Este adjetivo está, a su vez, relacionado con Fenicia (Phoenice, en latín), donde se producía la púrpura de mayor calidad.

${ }^{40}$ Curiosamente, la voz 'oriol' del Diccionario de autoridades hace referencia a un ave dotada de un plumaje de un color asociado al púrpura: 'Paxarito de color roxo baxo, que tiene enemistad con el cuervo, y el cuervo con él, quebrándose mutuamente los huevos' (s. v. oriol, Diccionario de autoridades, Madrid, RAE, 2013).

${ }^{41}$ A pesar de que los autores clásicos aproximan el aspecto del fénix al de las rapaces, cuando los primeros cristianos adaptan esta criatura al cristianismo lo hacen directamente a partir de las versiones más orientales y arcaicas, que pervivían en aquellas zonas. Por ello, es frecuente encontrar representaciones del fénix de estos primeros momentos del cristianismo (siglos II al v) que ensalzan su unión con el sol y la resurrección y que le otorgan un aspecto más parecido a un pavo o gallinácea. Aparecen en catacumbas, pinturas murales y mosaicos: «Asociado a la palmera sobre cuyas ramas se posa, representado entre llamas en el momento de la combustión, colocado sobre un montículo o portando nimbo y con rayos sobre su cabeza y con el plumaje característico de un pavo real» (Diego Barrado, «La representación del ave fénix como imagen de la Renovatio de la Roma altomedieval», Anales de Historia del Arte, $\mathrm{n}^{\circ}$ extra 1 (2010), pp. 171-185; p. 172).

${ }^{42}$ El fisiólogo. Bestiario medieval, Nilda Guglielmi (ed.), Madrid, Eneida, 2002, p. 135.

${ }^{43}$ Heródoto, Historia, II, LXXIII. 
bio de aspecto puede explicarse a partir de uno de los rituales que se celebraban en Heliópolis en torno a este mito:

En On-Heliópolis, el principal Templo del Sol egipcio, un águila con las alas pintadas era, según parece, quemada viva con especias en un nido de ramas de palmera para celebrar el acontecimiento. Esta águila representaba al dios Sol y la palmera estaba consagrada a su madre la Gran Diosa; el Sol había terminado su gran revolución y el águila solar volvía en consecuencia al nido para inaugurar una nueva Era del Fénix. Según la leyenda, de las cenizas del Fénix nacía un gusanito que poco después se convertía en un verdadero Fénix. De la información confusa de Herodoto acerca del Fénix se deduce que en On-Heliópolis se conservaba, siempre un águila sagrada, y que cuando moría la embalsamaban en un huevo de mirra redondo que la preservaba indefinidamente; luego consagraban otra águila ${ }^{44}$.

Heródoto afirma que las plumas del fénix son «en parte doradas, en parte de color carmesí $\rangle^{45}$. Estos datos hacen perfectamente compatible la identificación del ave fénix con el falcón oriol, pues ambos se caracterizan por poseer un plumaje dorado $0^{46} \mathrm{y}$ aspecto de rapaz (la forma y efigie del halcón, recordemos, es muy similar a la del águila, solo que algo más estilizada y de un tamaño inferior). Heródoto no otorga demasiada credibilidad al resto de referencias, que tienen que ver con su facultad más destacada: la capacidad para morir y volver a nacer cada quinientos años. Este último aspecto ha hecho del fénix un símbolo habitual de la eternidad ${ }^{47}$ :

Otra ave sagrada hay allí que sólo he visto en pintura, cuyo nombre es el de fénix. Raras son, en efecto, las veces que se deja ver, y tan de tarde en tarde, que según los de Heliópolis sólo viene al Egipto cada quinientos años a saber cuándo fallece su padre. Si en su tamaño y conformación es tal como la describen, su mote y figura son muy parecidas a las del águila, y sus plumas en parte doradas, en parte de color de carmesí. Tales son los prodigios que de ella nos cuentan, que aunque para mí poco dignos de fe, no omitiré el referirlos. Para trasladar el cadáver de su padre desde la Arabia al templo del Sol, se vale de la siguiente maniobra: forma ante todo un huevo sólido de mirra, tan grande cuanto sus fuerzas alcancen para llevarlo, probando su peso después de formado para experimentar

\footnotetext{
${ }^{44}$ Robert Graves, La diosa blanca, Madrid, Alianza Editorial, vol. 2, pp. 579-580.

${ }^{45}$ Heródoto, Historia, II, LXXIII.

${ }^{46}$ El plumaje dorado -junto al púrpura- es el más adecuado para el fénix, la más excelsa de las aves, que además está asociada a los dioses y el Sol: «El oro siempre ha sido el color de la reverencia y a su vez reverenciado. Parte de su atractivo reside en la escasez del mineral [...]. El oro siempre se ha utilizado para despertar admiración. [...] El intenso fulgor del oro, junto con su resistencia a deslustrarse, lo convierten en un emblema ideal para representar la divinidad» (Kassia St. Clair, op. cit., pp. 86-87).

${ }^{47}$ Juan Eduardo Cirlot, Diccionario de símbolos, Barcelona, Editorial Labor, 1992, p. 200.
} 
si es con ellas compatible; va después vaciándolo hasta abrir un hueco donde pueda encerrar el cadáver de su padre; el cual ajusta con otra porción de mirra y atesta de ella la concavidad, hasta que el peso del huevo preñado con el cadáver igual al que cuando sólido tenía; cierra después la abertura, carga con su huevo, y lo lleva al templo del Sol en Egipto. He aquí, sea lo que fuere, lo que de aquel pájaro refieren ${ }^{48}$.

Plinio el Viejo, en su Historia naturalis, incluye algunas de las referencias que ya aparecen en la descripción de Heródoto (aspecto de rapaz, plumaje dorado y púrpura). Desarrolla algo más la explicación del proceso de resurrección del fénix y ofrece detalles sobre el conocimiento y recepción del mito en su propio tiempo. Plinio el Viejo, como Heródoto, otorga también poca credibilidad a la historia, que considera más bien «una fábula»:

Dicen que Etiopía y la India crían aves de muy diversos colores e indescriptibles y la más famosa de todas, el fénix de Arabia (no sé si se trata de una fábula), única en todo el mundo y muy difícil de ver. Se cuenta que es del tamaño de un águila, con el brillo del oro en torno al cuello y el resto de color púrpura, con plumas rosas que adornan su cola azulada y con el ennoblecimiento de crestas en la garganta y de un copete de plumas en la cabeza. Manilio, aquel senador famoso por sus grandísimos saberes sin haber tenido maestro alguno, fue el que, entre los romanos, se refirió a él primero y con el mayor rigor. Señala que no ha existido nadie que lo haya visto comer, que en Arabia está consagrado al Sol, que vive quinientos cuarenta años y que, al envejecer, hace un nido con ramitas de canelo y de incienso, lo llena de aromas y muere sobre él. Añade que, después, de sus huesos y médulas nace primero como una larva y de él a continuación resulta el polluelo, y lo primero que hace es rendir las honras fúnebres debidas a su predecesor, y lleva el nido entero cerca de Pancaya, a la Ciudad del Sol, y allí lo deja en un altar. El mismo Manilio manifiesta que con la vida de este pájaro se cumple la revolución del Gran Año y que de nuevo retornan los mismos signos de las estaciones y las constelaciones, y que esto comienza en torno a mediodía, el día en que el Sol entra en el signo de Aries, y que el año de esta revolución en que él escribía, en el consulado de Publio Licinio y Gneo Cornelio, era el doscientos quince. Comelio Valeriano cuenta que el fénix voló a Egipto en el consulado de Quinto Plaucio y Sexto Papinio. Fue traído también a Roma durante la censura del emperador Claudio (en el año ochocientos de Roma) y expuesto en el Comicio, lo que está atestiguado por las Actas. Pero nadie dudaría de que era falso ${ }^{49}$.

Sin embargo, el aspecto más destacado de este fragmento de Plinio el Viejo es la mención a un rasgo de esta criatura que no aparece en Heródoto, pero que será parte inseparable de ella en los textos

\footnotetext{
${ }^{48}$ Heródoto, Historia, II, LXXIII.

${ }^{49}$ Plinio el Viejo, Historia natural, X, 2, 2.
} 
y representaciones realizados durante la Antigüedad tardía y la Edad Media. Se trata de las «crestas en la garganta» y el «copete de plumas» que coronan su cabeza, y que tal y como hemos analizado, estaban ya presentes en el mito egipcio. Será esta una característica propia del fénix. Tanto es así que el Bestiario de Don Juan de Austria (c. 1570), basándose en lo dicho por Plinio el Viejo, hace referencia prácticamente a estos mismos detalles (morfología de águila, color dorado), incluidos el copete y la cresta:

En Guinea y en la Yndia se crían aves estrañas y de diversas colores, entre las quales la tierra de Arabia cría la noble ave llamada fénix. Aunque dize Plinio que no sabe si esta ave la áy con verdad o si es conseja lo que della se cuenta. Pues dizen que no áy más que una en todo el mundo y que la ven pocas vezes. Della se cuenta que es del tamaño de un águila. El cuello dorado. Todo lo demás colorado y la cola verde y negra con unas plumas engeridas de color de rosa y en la cabeça tiene su cresta y penacho de plumas ${ }^{50}$.

La morfología de ave rapaz (sea de águila o de halcón) ayuda a identificar al falcón oriol con el ave fénix. Su característico color dorado (que siempre es propio del plumaje de esta criatura, a veces de forma completa, otras solo en el cuello) esclarece y fortalece aún más la identidad del falcón oriol. Uno de los bestiarios más bellos que se conservan de la Europa medieval, el Bestiario de Aberdeen ${ }^{51}$, ofrece un testimonio importante en este sentido: demuestra que durante el periodo medieval el ave fénix era representada con un plumaje de color completamente dorado y que poseía la morfología de una rapaz (Figs. 2 y 3 ; si bien el texto lo describe como púrpura que, como ya hemos analizado, adquiría tonalidades variadas en la tradición: «Fenix Arabie avis dicta quod colorem feniceum / habeat, vel quod sit in toto orbe singularis et / unica $[\ldots] »^{52}$. Las miniaturas del códice muestran, literalmente, a un «falcón oriol», un halcón completamente dorado, aunque sin penacho sobre la cabeza. Entre los folios 55r y 56v se encuentra la entrada dedicada al fénix, que sigue el contenido presente en los autores clásicos, incorporando al final un sentido didáctico, moral y teológico.

\footnotetext{
${ }^{50}$ Bestiario de D. Juan de Austria, Juan José García Gil y Pablo Molinero Hernando (eds.), Burgos, Siloé, 2000, p. 221.

${ }^{51}$ El Bestiario de Aberdeen se conserva en la Universidad de Aberdeen (Escocia), con la signatura ms. 24. Está datado en el siglo XII y está escrito en latín. Sigue la estructura de las Etimologías de Isidoro de Sevilla, una de sus principales fuentes junto al Physiologus, De partibus animalium de Aristóteles o la Historia natural de Plinio el Viejo, entre otras. Puede ser consultado en una copia digitalizada de la más alta calidad en la siguiente dirección: Bestiario de Aberdeen, ms. 24, Universidad de Aberdeen. En línea: <https://www.abdn.ac.uk/bestiary/> [consulta: 10/03/2019].

${ }^{52}$ Bestiario de Aberdeen, ed. cit., f. 55r.
} 

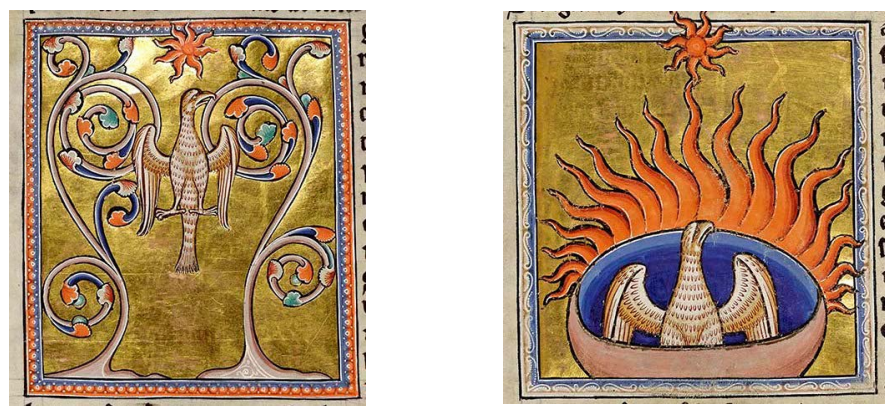

Figuras 2 y 3: El ave fénix del Bestiario de Aberdeen (ms. 24, ff. 55v y 56r)

El Fisiólogo, uno de los bestiarios más influyentes en la Europa de la Edad Media, es fuente del Bestiario de Aberdeen: ya en él es posible encontrar este tipo de alegorías moralizantes añadidas a la descripción de cada animal, aunque parece que las versiones más tempranas -fechadas entre los siglos II y v d. C. - no incluían este tipo de contenido ${ }^{53}$. Serán añadidas posteriormente, cuando el mito del fénix sea cristianizado y quede unido a la resurrección de Cristo ${ }^{54}$, por motivos evidentes. En la entrada del Fisiólogo dedicada al fénix, se describe el proceso vital del ave (de nuevo, dividido en periodos de quinientos años), se reconoce su carácter inmortal, su vinculación con la India, Heliópolis y el fuego y su aspecto de águila ${ }^{55}$. Nada se dice respecto del color de su plumaje ${ }^{56}$.

No obstante, la posesión del copete sobre la cabeza es el argumento que hace incuestionable la identificación del falcón oriol con el ave fénix ${ }^{57}$. Es fundamental, porque los fragmentos textuales anteriormente

${ }^{53}$ Guglielmi, ed. cit., pp. 10-11.

${ }^{54}$ «[...] Es en el Fisiólogo donde encontramos la asociación simbólica más antigua del fénix a la resurrección de Cristo, más que a la de los muertos» (Trad. propia de: Jaqueline Leclercq-Marx, «Drôles d'oiseaux. Le caladre, le phénix, la sirène, le griffon et la serre dans le Physiologus, les Bestiaires et les encyclopédies du XIII ${ }^{\mathrm{e}}$ siècle. Mise en perspective», en Chantal Connochie-Bourgne (ed.), Déduits d'oiseaux au Moyen Âge, Aix-en-Provence, Presses universitaires de Provence, 2009. En línea. DOI: http://dx.doi.org/10.4000/books.pup.4281).

${ }^{55}$ Guglielmi, ed. cit., p. 75.

${ }^{56}$ Son incontables las descripciones que se realizaron en obras medievales (enciclopedias, bestiarios, misceláneas) referidas al ave fénix. El propósito de este artículo no es dar cuenta pormenorizada de todas ellas, sino esclarecer la identidad del falcón oriol. Dada la relación de dependencia que existe entre aquellas y las referencias clásicas, no incluyo otras descripciones de esta criatura que se encuentran en testimonios como las Etimologías de Isidoro de Sevilla, el Liber floridus o el Libro de las maravillas del mundo de Jean de Mandeville, entre otras: el contenido, aunque con variaciones, difiere poco entre todas ellas.

${ }^{57}$ Tanto el color dorado como el penacho sobre la cabeza han sido las dos características fundamentales del ave fénix en las representaciones realizadas del mismo en la cultura occidental. Tal ha sido su fortuna que hoy es posible encontrar constantes referencia a ellas. Me serviré de tres ejemplos relevantes de entre los muchos que podría tomar: el primero de ellos tiene que ver con el logotipo de la antigua aseguradora española La Unión y el Fénix Español (fundada en 1879, desaparecida en 1998), formado por las efigies de Ganímedes y un fénix, 
presentados (Calila e Dimna y Libro del cavallero Zifar) no son los únicos registros medievales que existen del nombre falcón oriol. La pequeña iglesia de Santiago de Breixa (concejo de Silleda, Pontevedra) conserva un grupo de capiteles románicos de gran belleza e interés. Todos ellos representan a criaturas mitológicas (centauros, sirenas, arpías, grifos). Uno de estos capiteles contiene la talla en piedra de un ave con la forma de una rapaz: sus alas son largas y apuntadas, posee unas fuertes garras y un plumaje muy definido y detallado ${ }^{58}$. Todo ello encaja con la forma de los halcones, que precisamente se diferencian de las águilas por tener unas alas de aspecto más afilado y estrecho. Le falta la cabeza, que al parecer fue arrancada en algún momento para hacer sitio a un retablo moderno. Sin embargo, aún se conserva un notorio penacho o copete de plumas que originalmente habría de sobresalir de la nuca del ave. La mayor coincidencia no es ninguna de las que acabo de enumerar, absolutamente decisivas ya en sí mismas; lo es la inscripción que está grabada sobre una de las alas de piedra, en la que se pueden leer las palabras «falcón oriol» ${ }^{59}$ (Fig. 4).

de color dorado y que cuenta con un penacho sobre la nuca. Aún hoy se mantiene sobre la entrada de la Gran Vía de Madrid (Gran Vía, 68), en la cúspide del tejado del antiguo edificio que perteneció a esta compañía. El segundo caso es el de las cervezas ${ }^{\circledR}$ Grimbergen (Bélgica), producidas en la abadía del mismo nombre desde 1128. Fue destruida en tres ocasiones $(1142,1566,1798)$, por lo que los monjes, para ensalzar su propia capacidad de recuperación, decidieron adoptar como propios el emblema y el mote del fénix («Ardet nec consumitur»). En la actualidad, la marca que comercializa estas cervezas utiliza como logotipo un fénix completamente dorado, con forma de rapaz y dotado de un copete de plumas sobre la cabeza. Es, de manera literal, un «falcón oriol». Por último, es llamativo el caso del fénix de nombre Fawkes, que aparece en la novela y película de Harry Potter y la cámara secreta (J. K. Rowling): de nuevo, es un fénix con morfología de rapaz, que cuenta con una cresta que le sobresale de la nuca y que posee un plumaje dorado y carmesí.

${ }^{58}$ Es posible consultar en la página web de romanicoaragones.com un completo y minucioso reportaje fotográfico de este capitel y de todos los que se conservan en la iglesia de Breixa. Con todo, los datos que ofrece respecto de la relación del capitel con el Calila e Dimna son inexactos y no deben tenerse en cuenta. En Antonio García Omedes, «Breixa. Parroquial de Santiago (cont.)», Románico Aragonés (página web). En línea: <http://www.arquivoltas. com/11-Galicia/01-Breixa2.htm> [consulta: 10/03/2019].

${ }^{59}$ La iglesia de Santiago de Breixa (último tercio del siglo XII) es anterior a los textos castellanos en los que se documenta el término $(c .1251, c .1300)$, por lo que no pudo inspirarse en aquellos. Ninguna de las demás criaturas mitológicas que aparecen representadas en algunos de sus capiteles (muchas, con sus nombres también escritos: «serena» [sirena], «arpía», «sagitarios») son mencionadas en el Calila e Dimna ni en el Libro del caballero Zifar, por lo que este es otro motivo que dificulta que estas obras literarias le pudieran servir de fuente. Sin más testimonios, no se puede descartar que la inscripción se incluyese con posterioridad a la talla del capitel para precisar la identidad de la criatura. Tampoco que tomase como fuente alguna de las versiones del Calila que circularon por la Península Ibérica durante la primera mitad del siglo XIII, con anterioridad a la versión castellana. Me refiero a las versiones hebreas de Rabí Yoel y de Ya'aqob ben El'azar (María Jesús Lacarra, «El Exemplario contra los engaños y peligros del mundo: las transformaciones del Calila en Occidente», en Marta Haro Cortés (ed.), Exemplario contra los engaños y peligros del mundo. Estudios y edición, Valencia, Universitat de Valencia, 2007, pp. 15-41; p. 17). Por el momento no es posible determinar si alguna de estas versiones incluía al fénix, porque el texto de Rabí Yoel no ha conservado dicho fragmento (solo se conserva un manuscrito fragmentario del mismo) y la versión de Ya'aqob ben El'azar 


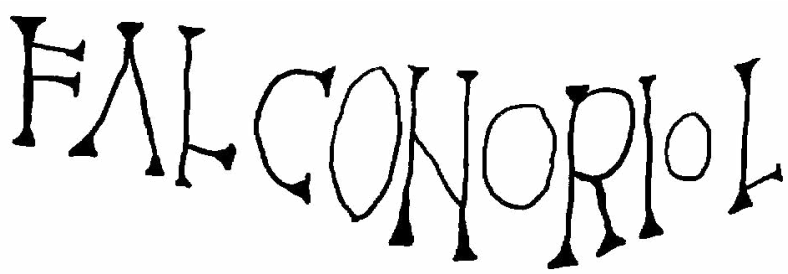

Figura 4: Rep. del grabado epigráfico del capitel 5 de la parroquia de Santiago de Breixa.

Este capitel [Fig. 5] se convierte, al combinarlo con el resto de datos literarios que ya han sido expuestos, en un argumento incuestionable que identifica como una misma criatura al ave fénix con el falcón oriol de la literatura medieval castellana. Al mismo tiempo, demuestra que no se trata de un ave real: ninguna rapaz de la región paleártica ${ }^{60}$ posee un penacho de plumas como el que se atribuye al fénix, presente en la representación de Santiago de Breixa. Prueba -y enfatiza- la naturaleza mitológica del falcón oriol, que es representado junto a otras criaturas irreales. El ave del capitel de Breixa no es una rapaz real, sino un animal fabuloso. Es muy probable que el penacho quedase unido a la figura del fénix ya durante la etapa del mito durante el Antiguo Egipto, donde era identificado con la garza imperial (Ardea purpurea) que, como otras garzas, sí posee este rasgo morfológico sobre su cabeza.

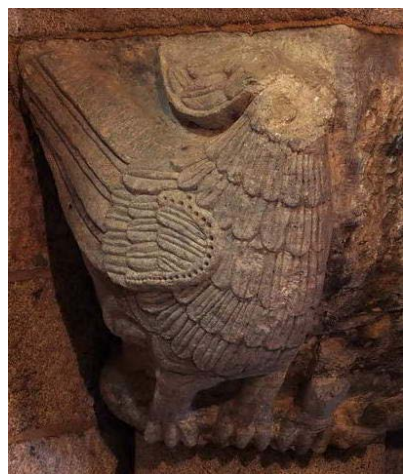

Figura 5: Capitel de la Iglesia de Breixa (Silleda, Pontevedra).

(C) arquivoltas.com, A. García Omedes.

lo elimina del exemplum (Deux versions hébraïques du livre de Kalilâh et Dimnâh, Joseph Derenbourg (ed.), París, F. Vieweg Librarie-Editeur, 1881). La opción más probable es que el nombre de falcón oriol se incluyera en la representación del capitel porque este era uno de los nombres por los que fue conocida el ave fénix en la Península Ibérica durante el siglo XIII.

${ }^{60}$ El Paleártico es la ecozona de mayor extensión en que se divide la Tierra. Comprende los continentes completos de Europa, Asia (con el Himalaya como frontera meridional) y norte de África, así como la zona norte de la Península Arábiga. 
Por último, disponemos de otro argumento adicional que apuntala definitivamente esta identidad hasta ahora desconocida. Se trata de la versión árabe del Calila e Dimna ${ }^{61}$, que incorpora en su estructura narrativa prácticamente los mismos episodios que es posible encontrar en la versión castellana del siglo XIII, puesto que la traducción castellana es bastante fiel al modelo árabe del que parte. Es el caso del pasaje en que es mencionado el falcón oriol ${ }^{62}$, que en el texto árabe recibe el nombre de Simurg. El Simurg Anqa o Simorgh es el de la criatura equivalente al ave fénix en la mitología persa, de la que fue adoptada por la cultura árabe. Anida entre las ramas del árbol de la ciencia (en la montaña de Qaf, que rodea el mundo y señala sus límites) y posee el mismo carácter inmortal que aquel ${ }^{63}$. Está asociado con la divinidad y es el rey de todos los pájaros ${ }^{64}$, como el falcón oriol:

La asamblea de pájaros propuso:

-El Simurg es hijo del viento y rey nuestro. Ven con nosotros a pedirle que se nos aparezca y para quejarnos de lo que ha hecho la marea y rogarle que se vengue de ella con su realeza.

Así que se presentaron ante el Simurg con el chorlito, éste le pidió que le asistiera y el Simurg aceptó. Entonces fue cuando le contaron lo ocurrido y le suplicaron que fuese volando a pelear con la marea. Él a todo accedió.

Cuando la marea supo que el Simurg se dirigía hacia ella con todos los pájaros, tuvo miedo de enfrentarse a un rey contra el que nada podía, devolvió los pollos al chorlito, hizo las paces con él y el Simurg se fue ${ }^{65}$.

Curiosamente, en culturas tan distanciadas de la occidental como la china también «el Fénix es el emperador de todas las aves y simboliza al sol ${ }^{66}$. Ese carácter regio, como ya hemos visto, es exactamente el mismo que posee el falcón oriol. Resulta una obviedad mencionarlo, pero no conviene olvidar que en castellano el término fénix posee ese mismo significado: hace referencia a la persona u objeto más destacado

\footnotetext{
${ }^{61}$ Benalmocaffa, ed. cit.

${ }^{62}$ Calila e Dimna, ed. cit., pp. 166-167.

${ }^{63}$ Ibid. p. 146.

${ }^{64}$ En El lenguaje de los pájaros (siglos XII-XIII), obra de carácter místico y sufí, treinta mil aves deciden ir a buscar al Simurg para encontrarse con la divinidad. «Su nombre es Simurg, el rey de los pájaros. / [...] Su nombre no está a la altura de cualquier mortal. / [...] Nadie hay de valor en los dos mundos que haya podido discutir su dominio. Él siempre ha sido el rey absoluto, en la altura de su perfección está sumido» (Ud-din Attar, ed. cit., est. 713-718). Quedan en relación el poder supremo de Dios -Alá-y Simurg, que somete a todos los elementos terrenales, entre ellos el mar: «El mar quemó rindiéndolo / y a la montaña, de temor, entristeció (Farid Ud-din Attar, El lenguaje de los pájaros. Clara Janés y Said Garby (eds.), Madrid, Alianza Editorial, 2015, est. 9). El mar es un elemento personificado en la obra. Esta es esencialmente la misma acción que realiza el falcón oriol en el Calila cuando acude en ayuda de los tittuy y consigue que estos recuperen sus pollos.

${ }^{65}$ Benalmocaffa, ed. cit., pp. 146-147.

${ }^{66}$ Cirlot, op. cit., p. 204.
} 
y apreciado por sus cualidades, lo que le otorga una jerarquía superior al resto de contendientes con los que se compara ${ }^{67}$. Famoso es el apelativo con que es conocido Lope de Vega, el mayor dramaturgo de su época y «fénix de los ingenios».

De forma significativa, José Alemany, en su doble edición de las versiones árabe y castellana del Calila $^{68}$, utiliza en el texto árabe los nombres de «fénix» y «águila fénix» y no emplea el de Simurg. En el texto castellano que edita aparece el mismo término de «falcón oriol» $\rangle^{69}$. Para el cotejo se sirve de la edición del texto árabe de Louis Cheikho, que utiliza como texto base un manuscrito que encontró en un monasterio cercano a Beirut, datado en $1339^{70}$ (aunque, según afirma, es transmisor de una versión fiel al original de Benalmocaffa). En el siguiente apartado analizaré las implicaciones que puede tener la versión del texto de Cheikho.

Los procesos de transmisión textual suelen modificar, en ocasiones sustancialmente, el contenido de la obra en cuestión. En el caso del Calila e Dimna, que durante la Edad Media fue uno de los textos más difundidos, este tipo de cambios son más palpables que en otras colecciones de cuentos. Así, el Directorium vitae humanae alias parabolae antiquorum sapientium (c. 1262-1268), versión latina del Calila, fue realizada por Juan de Capua a partir de una versión hebrea no emparentada con la castellana (forma parte de la rama occidental y fue traducida antes que la versión castellana ${ }^{71}$, durante la primera mitad del siglo XIII). Consiguió una gran difusión por todo el continente europeo. Durante el siglo XV, esta versión latina fue traducida al castellano con el título de Exemplario contra los engaños y peligros del mundo, obtuvo una buena fortuna editorial y permitió que el Calila e Dimna fuese conocido por los lectores de la época ${ }^{72}$. En el pasaje en el que la versión castellana menciona al falcón oriol como rey de todas las aves (analizado anteriormente), el Exemplario no incluye a este ser, ni tampoco al fénix ni al Simurg de las versiones árabes. En su lugar, la cigüeña (Ciconia ciconia) se convierte en la soberana de todas las aves, y a ella acuden los supuestos chorlitejos para recuperar los pollos que les ha sustraído la fuerza del mar. Por supuesto, la cigüeña no es reina de las aves en ningún testimonio previo de la tradición:

67 'Persona o cosa exquisita o única en su especie' (s. v. fénix, DRAE).

${ }^{68}$ La antigua versión castellana del Calila y Dimna cotejada con el original de la misma, José Alemany Bolúfer (ed.), Madrid, Librería de los sucesores de Hernando, 1915.

${ }^{69}$ Ibid., p. 139

${ }^{70}$ Kalilah et Dimnah, d'après le plus ancien Manuscrit arabe daté, Louis Cheikho (ed.), Beirut, Imprimerie Catholique, 1905, pp. 24-25

${ }^{71}$ María Jesús Lacarra, op. cit., p. 16.

${ }_{72}$ «Podemos decir, sin temor a equivocarnos, que los lectores del siglo XvI conocieron los cuentos del Calila y Dimna a través de esta obra, ya que la difusión de la temprana versión alfonsí fue muy limitada, restringida a círculos cortesanos y nobiliarios [...]» (ibid., p. 21). 
E sacando ende sus pollos quando fueron ya crecidillos, las ondas muy grandes de la furia del mar los llevó, de lo qual el masclo quedó muy confuso. Con todo eso por dexar de ser porfioso, llamó a consejo quantas aves pudo hallar e todas juntas fueron a buscar la cigüeña, que en aquellas partes reinaba sobre ellas. E quando fueron en su presencia, el padre de los pollos perdidos como dañado e cuyo interese los havía ajuntado le dixo: «Señora, habitando en el orillo del mar muy seguros, mi mujer y yo hizimos allí nuestro nido [...]».

Oída su petición, començó de se sonreír la cigüeña $[\ldots]^{73}$.

El cambio se debe a la inevitable introducción de variantes propia de los ya mencionados procesos de transmisión textual. De hecho, no es extraño que durante alguna de estas fases, un copista sustituyera al falcón oriol, fénix o Simurg por la cigüeña, ave muy frecuente en Europa y que cuenta con una morfología relativamente similar a la de las garzas.

\section{VITALIDAD Y USO DE LOS NOMBRES FÉNIX Y FALCÓN ORIOL}

El término fénix está documentado en otros testimonios literarios castellanos del periodo medieval. Sin embargo, parece que su uso no llegó a solaparse en el tiempo con el apelativo de falcón oriol. Fénix fue utilizado de forma más habitual desde finales del siglo XIV, mientras que falcón oriol únicamente se documenta en testimonios del siglo XIII o anteriores: en el Calila e Dimna (c. 1251), el Libro del cavallero Zifar (c. 1300) y el capitel de la iglesia románica de Santiago de Breixa (último tercio del siglo XII). Por su parte, la mención existente en el poema de Elena y María (c. $1250^{74}$ ) del rey Oriol puede no ajustarse a estos mismos planteamientos, tal y como ha sido expuesto anteriormente.

El testimonio castellano más antiguo en que se documenta el término fénix es la Estoria de España de Alfonso X (c. 1270), en el que es mencionado hasta en tres ocasiones. Dichos fragmentos evidencian que el vocablo fénix causaba cierta extrañeza en aquel momento: cuando es citado se hace hincapié en que dicho nombre es tomado directamente de la fuente correspondiente («la aue que dizen fenix» ${ }^{75}$ ). También aparece

73 Transcripción propia de: Exemplario contra los engaños y peligros del mundo, Inc. 1994, Zaragoza, Pablo Hurus, 1493, f. 25v.

${ }^{74}$ Sigo en la datación de Elena y María los argumentos de E. Franchini, el gran estudioso de los debates literarios medievales, que adelanta la fecha de composición respecto de la ofrecida por Menéndez Pidal (que propuso «el último tercio del siglo XIII», más bien c. 1280; Menéndez Pidal, art. cit., p. 78). Franchini se basa para ello en argumentos como la gran abundancia de la apócope extrema, especialmente en las formas verbales, que solo puede justificarse de esta manera en una copia manuscrita del siglo xIV, cuando la apócope extrema ya no existía. Franchini piensa que la fecha de composición del original puede ser adelantada incluso a «los años 20 ó 30 del siglo XIII» (Enzo Franchini, Los debates literarios en la Edad Media, Madrid, Ediciones del Laberinto, 2001, p. 104).

${ }^{75} «[\ldots]$ E fue natural duna cibdat que dixieron fenis. e fue assi llamada por que era tan uiciosa que tenien que no auie compannera en el mundo. assi cuemo ell aue fenix que es sola 
en la cuarta parte de la General Estoria (c. 1280), en un pasaje en que un anciano informa a Alejandro Magno sobre la presencia del fénix ${ }^{76}$. Los demás testimonios en los que es citada el ave fénix por este nombre son posteriores (y también ya mucho más abundantes), todos ellos de los siglos XIV y xv: la Gran crónica de España de Fernández de Heredia (1385), el Viaje de Juan de Mandevilla (c. 1400, ms. M.III.7), el Cancionero de Juan Fernández de Íxar (siglo xv), el Libro de las paradoxas de Alonso Fernández de Madrigal (1437), el Comentario a la «Coronación del Marqués de Santillana» de Juan de Mena (c. 1439), el Laberinto de Fortuna de Juan de Mena (1444) o el Jardín de nobles doncellas de fray Martín de Córdoba (1468), entre otros ${ }^{77}$.

Es evidente, tras analizar estos datos, que el nombre de falcón oriol para referirse al ave fénix estuvo extendido en la Península Ibérica durante todo el siglo XIII, quedando en desuso a partir de la centuria siguiente. Desde entonces se impuso la denominación de fénix, probablemente por la influencia y prestigio de las obras latinas que lo incluían y que fueron tomadas como referencia en las obras producidas a partir de aquel momento.

Sería necesario contar con más datos para explicar con exactitud la utilización del término falcón oriol en la Península durante el siglo XIII. El primer testimonio conocido en que aparece es el capitel de la iglesia de Santiago de Breixa, del último tercio del siglo XII. A su vez, la primera evidencia literaria que documenta su uso es el fragmento del Calila e Dimna, traducido del árabe al castellano hacia 1251. Estos datos, sumados al fragmento del texto árabe transcrito por Cheikho (que menciona muy significativamente al «águila fénix»), hacen posible que el origen del término falcón oriol se encuentre en el propio texto árabe. En primer lugar, la inclusión de la palabra águila en el original árabe puede explicar con facilidad la derivación en el falcón del texto castellano. Sin embargo, la explicación del origen del adjetivo oriol quizás se deba a otro motivo. Falcón oriol es un nombre completamente descriptivo, que parece haber sido creado ad hoc a partir la contemplación de una miniatura semejante a las contenidas en el Bestiario de Aberdeen (figs. 2 y 3). Es probable que, cuando el texto árabe del Calila fue traducido al

e no a conpannera ninguna[...]»; «[...] aun segund diz plinio; y auien la aue que dizen fenix, e por esto entendet que segund aquellos que lo cuentan que destas aues mas a de una $[\ldots] » ; «[\ldots]$ E aquel que auie nombre fenix poblo una cibdat e pusol nombre fenicia [...]» Los datos han sido extraídos de: RAE: Banco de datos (CORDE), Corpus diacrónico del español. En línea: $<$ http://www.rae.es> [consulta: 21/03/2019].

${ }^{76}$ «[...] aquella aue que sie en aquel aruol de que tu te marauillas. es la aue fenix $\&$ yendo aun empos esto mas adelant por essa selua. llegaron al aruol que era connosçudamient del sol $\&$ de la luna [...]». RAE: Banco de datos (CORDE), Corpus diacrónico del español. En línea: $<$ http://www.rae.es> [consulta: 21/03/2019].

${ }^{77}$ Esta relación de testimonios ha sido obtenida de la base de datos del CORDE. S. v. fénix, fenix. RAE: Banco de datos (CORDE), Corpus diacrónico del español. En línea: $<$ http://www. rae.es> [consulta: 21/03/2019]. 
castellano durante la época alfonsí, el traductor se fijase en alguna de las abundantes miniaturas que podría incluir el original árabe del que partía para desarrollar su labor. Prueba de ello es el carácter visual y oportuno de la denominación falcón oriol, en la que se hace referencia a las dos características más notorias de esta criatura: su aspecto de falcónido y el color dorado de su plumaje. No resultaría nada extraño, pues en los muchos manuscritos que conservan la versión árabe del Calila se incluyen cientos de miniaturas que representan en su mayoría a los animales y personajes humanos de los exempla contenidos en el texto. A modo de ejemplo, únicamente en la Biblioteca Nacional de París se conservan seis manuscritos ${ }^{78}$ de esta versión árabe del Calila que están decorados con miniaturas. Si extendemos el cómputo a una escala global, existen veintinueve manuscritos diferentes -solo de la versión árabe- que incluyen miniaturas o ilustraciones junto al cuerpo del texto ${ }^{79}$.

Tras realizar una revisión de todos los manuscritos de la versión árabe del Calila a los que ha sido posible acceder (más de una decena), se hace evidente que casi todos ellos repiten las mismas escenas que ya están presente en otros testimonios, porque se inspiran sin tapujos en el manuscrito del que copian. Al respecto, no ha sido posible encontrar ninguna miniatura que represente el pasaje del ave fénix y la marea. Ello aumenta el valor de la siguiente ilustración ${ }^{80}$ [Fig. 6], que muy posiblemente represente al Simurg, con su característico plumaje carmesí y dorado. Están también presentes los colores verde y azul, que no son extraños en algunas descripciones antiguas del mito. Posee una pequeña cresta que le sale de la nuca: coincide en esto con la representación del capitel de Santiago de Breixa. Son llamativos algunos rasgos ajenos al fénix tradicional, como la bicefalia o las decoraciones con forma de pez que hay en las puntas de sus alas. Está acompañado por varias aves -que permanecen en un segundo plano- sobre las que ejerce su soberanía.

${ }^{78}$ Son los manuscritos con las siguientes signaturas: Arabe 3465, Arabe 3467, Arabe 3470, Arabe 3472, Arabe 3475 y Arabe 5881 de la sección árabe. Otros tres presentan espacios vacíos destinados a recibir ilustraciones que nunca fueron incluidas (mss. Arabe 3466, Arabe 3469, Arabe 3478). Los demás (ocho testimonios) no están iluminados: mss. Arabe 3468, Arabe 3471, Arabe 3473, Arabe 3474, Arabe 3476, Arabe 3477, Arabe 3479, Arabe 3480. En Aida El Khiari, Kalîla wa Dimna. Manuscrits à peintures dans le monde islamique, à la BnF et dans les collections mondiales. En línea: $<\mathrm{https} / / \mathrm{kwd}$.hypotheses.org/tag/kalila-wa-dimna $>$ [consulta: 22/03/2019].

${ }^{79} \mathrm{El}$ dato lo aporta, de nuevo Aida El Khiari, investigadora asociada de la Universidad de la Sorbona y la Biblioteca Nacional de Francia (París), que forma parte del proyecto Kalîla wa Dimna. Manuscrits à peintures dans le monde islamique, à la BnF et dans les collections mondiales (dirigido por Annie Vernay-Nouri, BNF, y Eloïse Brac de la Perrière, Université La Sorbonne). Se conservan manuscritos en países como Alemania, Arabia Saudí, Canadá, Marruecos o Turquía, entre otros muchos.

${ }^{80} \mathrm{Se}$ encuentra en el folio 74v del ms. Arabe 3475 (París, BNF). Fue copiado en 1761 por Abd al-Rawf al-Sanğalafí, probablemente en Egipto. A pesar de su fecha tardía, es un testimonio de importancia porque es copia del ms. 3655 (Rabat, Bibliothèque Royale). En Gallica. Base de datos de la BNF. En línea: <https://archivesetmanuscrits.bnf.fr/ark:/12148/cc31371s > [consulta: 20/03/2019]. 


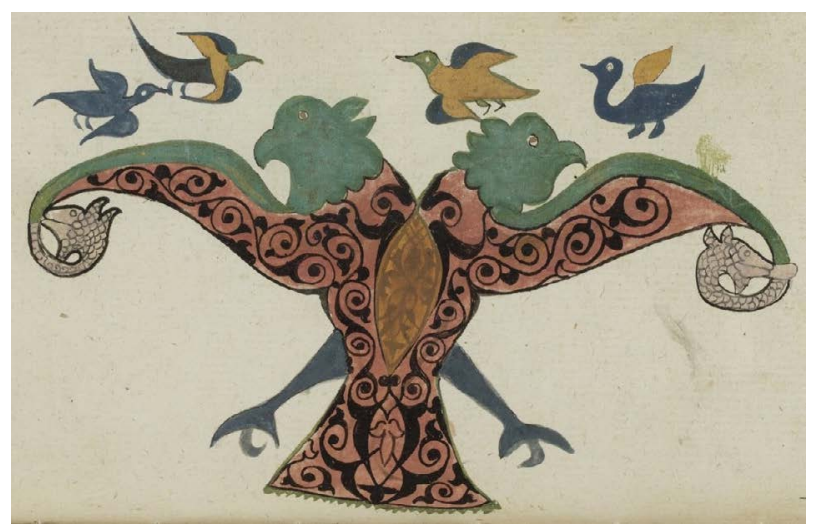

Figura 6: Simurg o ave fénix, soberano de todas las aves (f. 74v, ms. Arabe 3475, BNF, París).

\section{Conclusiones}

Todas las pruebas presentadas sustentan con seguridad la identificación del fénix y el Falcón oriol como una misma criatura, que adoptó esta doble denominación en la Península Ibérica durante la Edad Media. El uso del nombre falcón oriol ha quedado perfectamente documentado entre los siglos XII y XIII. Era este un modo muy accesible de denominar a un ave que se caracteriza precisamente por su color dorado y aspecto de rapaz. Por su parte, la representación encontrada en el capitel de la iglesia de Breixa, la miniatura existente en el Bestiario de Aberdeen y la alusión al Simurg (o «águila fénix») en la versión árabe del Calila convierten en irrefutable esta identificación que, hasta la fecha, no había sido descrita. A partir del siglo XIV se impondrá la utilización del término fénix para hacer referencia a esta criatura, quedando en desuso el de falcón oriol. Ello pudo deberse al gran influjo de las traducciones de textos de la tradición latina, que se referían de forma directa al fénix a partir del siglo XIV.

Los rasgos físicos que comparten el fénix y el falcón oriol son los siguientes: color dorado, forma de rapaz y penacho de plumas que sobresalen de la cabeza. Esta última característica es determinante: ningún ave rapaz posee un copete de plumas sobre la nuca. Ambos son los soberanos del resto de las aves del mundo, con una jerarquía superior a la del águila en todos los casos. La ya citada mención al Simurg que se realiza en el texto árabe del Calila con la misma función que desempeña el falcón oriol en la versión castellana se convierte en otro argumento sólido: permite identificar al fénix y al falcón oriol como dos denominaciones diferentes que hacen referencia a un mismo ser mitológico. El nombre de falcón oriol hubo de ser relativamente popular, pues fue recogido en dos de las obras literarias más destacadas de dicho periodo (Calila 
e Dimna y Libro del cavallero Zifar) y en el capitel de la mencionada iglesia de Santiago de Breixa.

Cuestión más compleja -y quizás independiente de la anterior- es la identificación simbólica del rey Oriol en el debate de Elena y María, que pertenece a un contexto literario diferente al del Calila o el Zifar. De todos los casos analizados, es el único que no permite ser taxativo al respecto. Dado el carácter incompleto del poema y la inexistencia de más datos, es posible realizar dos interpretaciones: si se atiende a la importancia de la temática amorosa en esta composición, el rey Oriol podría ser identificado con una oropéndola, que es, junto al ruiseñor, el ave más llamativa en sotos y riberas fluviales de toda la Península durante la primavera. Su melodioso canto y su plumaje dorado serían, para el autor del poema, atributos más que adecuados para considerarlo soberano y juez del amor en el plano simbólico. No obstante, no hay constancia de ninguna otra obra literaria en la que la oropéndola quede unida a simbologías amatorias, más allá de su cercanía con el ruiseñor. Tampoco existe ningún testimonio que muestre a este paseriforme como soberano de todas las aves: ambos son obstáculos importantes que impiden aceptar esta hipótesis.

Más probable -aunque no segura- parece la segunda interpretación: Oriol gobierna, tal y como ha sido explicado con anterioridad, una alegre corte medieval compuesta exclusivamente por aves. Por ello, es posible reconocer a este falcón oriol o fénix en la figura del rey Oriol, dado que dicha criatura sí cuenta con una tradición que respalda su jerarquía sobre el resto de sus congéneres. Ambos comparten una posición dominante sobre las demás aves y un nombre coincidente (oriol), aunque el texto del debate no ofrece ningún detalle adicional que permita ser categórico al respecto. El mayor inconveniente que impide aceptar por completo esta hipótesis es la ausencia del sustantivo falcón en el apelativo regio, tal y como sucede en el resto de los casos analizados. Futuros trabajos tratarán de dar respuesta a las nuevas incógnitas que han surgido tras esta investigación. 


\title{
$\cos$
}

\section{LA HISTORIA DEL FALCÓN ORIOL Y DEL AVE FÉNIX EN LA LITERATURA MEDIEVAL CASTELLANA}

\begin{abstract}
RESUMEN: Este artículo analiza la naturaleza e identidad del falcón oriol, mencionado en obras castellanas medievales de primer orden (Calila e Dimna, Libro del cavallero Zifar, Elena y María) como soberano de todas las aves. Esta es la denominación que, durante el siglo XIII, recibió el fénix en la Península Ibérica, una de las criaturas mitológicas más importantes de las culturas europeas y orientales. A lo largo de más de dos milenios, su aspecto ha variado notablemente: primero adquirió el aspecto de una garza, después su efigie se asimiló a la de las rapaces. El color dorado que posee su plumaje y otros testimonios de incuestionable valor (relación con el Simurg, representaciones escultóricas, etc.) permiten esclarecer su identidad que, hasta el momento, había sido ignorada por la crítica. Para ello, se analizará la etimología del nombre oriol, serán estudiadas las aves que tradicionalmente han sido utilizadas como símbolos del poder y se examinará el desarrollo del mito del fénix desde el Antiguo Egipto hasta la Edad Media.
\end{abstract}

Palabras Clave: fénix, Oriol, simbología, rey de las aves, Calila e Dimna.

THE HISTORY OF THE FALCÓN ORIOL AND THE PHOENIX IN MEDIEVAL CASTILIAN LITERATURE

ABSTRACT: This article analizes the nature and identity of the falcón oriol, mentioned on Spanish medieval works of relevance (Calila e Dimna, Libro del cavallero Zifar, Elena y María) as king of birds. This is the name given to the phoenix, which is one of the most relevant mythological creatures of European and Eastern cultures, in the Iberian Peninsula during the 13th century. Throughout more than two millennia, its appearance has varied remarkably: first it acquired the aspect of a heron, then its effigy was assimilated to that of the raptors. Its golden plumage and other testimonies of unquestionable value (relationship with the Simurg, sculptural representations, etc.) allow us to know the identity of this bird that, until now, was ignored by critics. Therefore, it will be analyzed the etymology of the name oriol, the birds that have traditionally been used as symbols of power and the development of the phoenix myth from Ancient Egypt to the Middle Ages.

KeYwOrds: phoenix, Oriol, symbology, king of birds, Calila e Dimna. 